\title{
The occurrence of Sumatran Tiger (Panthera tigris sumatrae) in an industrial plantation forest area, North Sumatra, Indonesia
}

\author{
Pindi Patana $^{1}$, Meta Winda Saputri ${ }^{1}$, and King Marpatasino ${ }^{2}$
}

${ }^{1}$ Faculty of Forestry, University of North Sumatra, Jl. Tri Dharma Ujung No. 1, Kampus USU, Medan 20155, Indonesia ${ }^{2}$ PT. Toba Pulp Lestari Tbk., Porsea Sub District, Toba Samosir District 21174, North Sumatra Province, Indonesia

Corresponding author: Pindi Patana, pindipatana2000@gmail.com

\begin{abstract}
Sumatran tiger lives in the remaining forests on the Sumatra island, both in conservation and production areas. There are not many tiger monitoring activities conducted in production forest. Using camera traps this occupancy survey of Sumatran tiger (Panthera tigris sumatrae) carried out in a plantation forest area of PT. Toba Pulp Lestari (PT. TPL) to obtain information and monitor tiger presence in the area. However, there were no Sumatran tigers captured by the camera traps during the occupancy activities. The existence of Sumatran tiger was proven by the finding of footprints and scrapes. Other species were photographed by the camera traps, such as marbled cat (Pardofelis marmorata), pig-tailed monkey (Macaca nemestrina), treeshrew (Tupaia sp.), Asian palm civet (Paradoxurus hermaphroditus), lizards (Eutropis sp.), Hoogerwerf's pheasant (Lophura hoogerwerfi), wood mouse (Apodemus sylvaticus) as well as birds. It is assumed that the Sumatran tiger didn't cross the location of research during the camera installation period. However, there are several other reasons why Sumatran tigers weren't captured by camera traps, such as the camera traps observation time was too short and didn't cover a larger area, so it lessens the opportunity of encounter with Sumatran tiger.
\end{abstract}

\begin{abstract}
ABSTRAK
Harimau Sumatera hidup di hutan yang masih tersisa di pulau Sumatera, baik di kawasan hutan konservasi maupun hutan produksi. Kegiatan pemantauan harimau di hutan produksi belum banyak dilakukan. Dengan menggunakan camera trap, survei okupansi harimau sumatera (Panthera tigris sumatrae) ini dilakukan di areal konsesi hutan tanaman industri PT. Toba Pulp Lestari (PT. TPL) untuk mendapatkan informasi dan memantau keberadaan harimau di kawasan tersebut. Namun, tidak ada harimau sumatera yang terfoto oleh kamera trap selama kegiatan survei okupansi. Keberadaan harimau sumatera dibuktikan dengan ditemukannya jejak tapak dan cakaran. Selain itu, terdapat ppesies lain yang terfoto oleh kamera trap, seperti kucing batu (Pardofelis marmorata), beruk (Macaca nemestrina), tupai tanah (Tupaia sp.), musang pandan (Paradoxurus hermaphroditus), kadal (Eutropis sp.), sempidan aceh (Lophura hoogerwerfi), tikus hutan (Apodemus sylvaticus) serta burung. Diasumsikan bahwa harimau sumatera tidak melintasi lokasi penelitian selama masa pemasangan kamera. Namun, terdapat beberapa alasan lain mengapa harimau sumatera tidak terfoto kamera trap, seperti waktu pengamatan kamera trap yang terlalu singkat dan tidak mencakup area yang lebih luas, sehingga memperkecil peluang perjumpaan dengan harimau sumatera.
\end{abstract}

Keywords: Sumatran tiger, camera traps, plantation forest, North Sumatra

\section{INTRODUGTION}

Sumatran tiger (Panthera tigris sumatrae Pocock, 1929) is one of three tiger subspecies in Indonesia. Sumatran tigers are protected species based on the Ministry of Environment and Forestry Regulation No. P.92 of 2018 and included in the Appendix I category of CITES (Convention on International Trade in Endangered Species of Wild Flora and Fauna). Currently, the number of Sumatran tiger population is rapidly decreasing and getting harder to find in the natural habitat from time to time (Sumitran \& Oktorini, 2014).

Declining the number of Sumatran tiger population is caused by various factors, such as the forest area is narrowed down due to land conversion for agricultural purposes, local inhabitant settlements, and industrial land which contribute to the decreasing number of

Submitted 8 February 2021; Accepted 23 March 2021
Sumatran tiger population. The declining rate of the Sumatran tiger population was triggered by the so-called "The Evil Quartet", or the term for habitat degradation and fragmentation, conflict with humans, overexploitation of natural resources, and exponential extinction (Sriyanto, 2003).

Tiger habitat is usually in lowland to mountainous rainforests at the altitude of $0-3,000 \mathrm{~m}$ above sea level (asl). Sumatran tigers require three basic needs, which are availability of prey, water sources, and dense vegetation to catch its prey (Ganesa \& Aunorrohim, 2012). Their most active time period is between $2 \mathrm{pm}$ in the afternoon and 10pm in the evening (Priatna et al., 2012). However, forests on the island of Sumatra, which are the natural habitat of Sumatran tigers, have been converted into plantations, agriculture and settlements area. Within their natural habitat in 
Sumatra, wild tigers utilize vegetation cover of plantation/regrowth (bush/young secondary forest with very high intensity (Priatna et al., 2012). Nowadays, Sumatran tigers could be found in plantation, agricultural and residential areas due to the limited space for movement and the difficulty of finding prey and eventually end up having conflicts with humans. Direct hunting of tigers and their prey also contribute greatly to the decline in the Sumatran tiger population in the wild (Sinaga, 2004).

Sumatran forests, which are natural habitats for Sumatran tigers, are having its forest cover area decreased significantly from time to time. Forest cover on the island of Sumatra was still $80 \%$ of the total land area in 1950. In 1985, the forest cover was reduced to $49 \%$. The forest area decreased into $35 \%$ of total land area based on 1997 survey. The change or forest cover in Sumatra from 1985-1997 was around 6.7 million Ha (FWI / GFW, 2001).

The main objective of this study is to obtain information of tiger presence in industrial plantation forest concession area, which is dominated by monoculture of Eucalyptus trees, as a basis for routine tiger monitoring activities.

\section{METHODS}

The study was carried out from March to November 2020 in an industrial plantation forest concession area that is dominated by monoculture of Eucalyptus trees at the Aek Nauli Sector, PT. Toba Pulp Lestari (PT. TPL). It is located in Sosor Ladang Village, Porsea Sub District, Toba Samosir Regency, North Sumatra. The area of the concession in the Aek Nauli Sector is 20,428 ha or around $10.9 \%$ from the total of concession area (Figure 1).

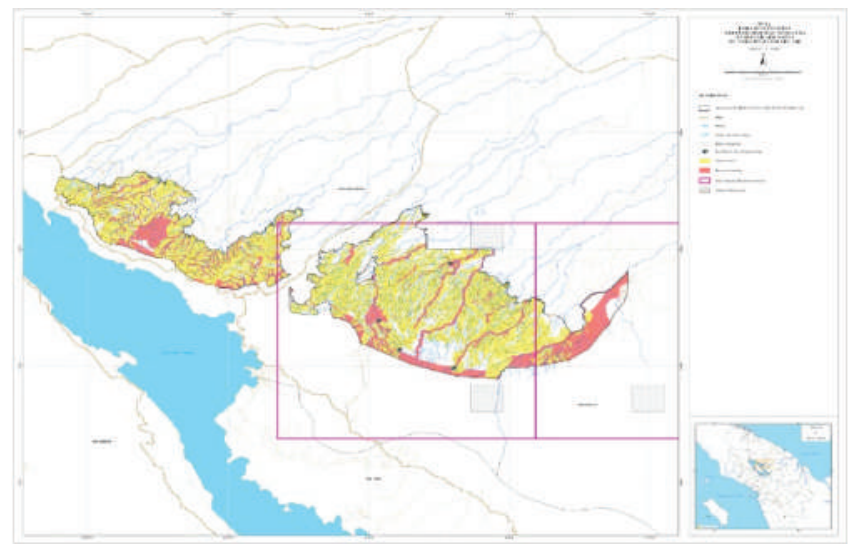

Figure 1. Map of the study area within protected area (red) of Aek Nauli Sector in the concession of PT. TPL, North Sumatra.

For the data collection, camera traps were employed as a main tool of observation. Global Positioning System (GPS), compass, memory card, and digital camera were also used as supporting research equipment. All data gathered from the field were analysed using software of Microsoft Excel as well as ArcGIS 10.5.

Camera traps were placed on the trail where tiger signs were found during tiger sign-based occupancy survey was conducted previously in this area (Figure 2). All camera traps were set up at a height of $30-40 \mathrm{~cm}$ from the ground level and at a distance of 2-3 meters from the target trail. The spacing between camera trap station was between $1.5-3 \mathrm{~km}$, and at every station placed two cameras that set up in pair for allowing us to identify the stripes at the right and left sides of a tiger. Camera traps collected data in the field continuously for three months and were visited every one or two weeks for maintenance and data retrieval.

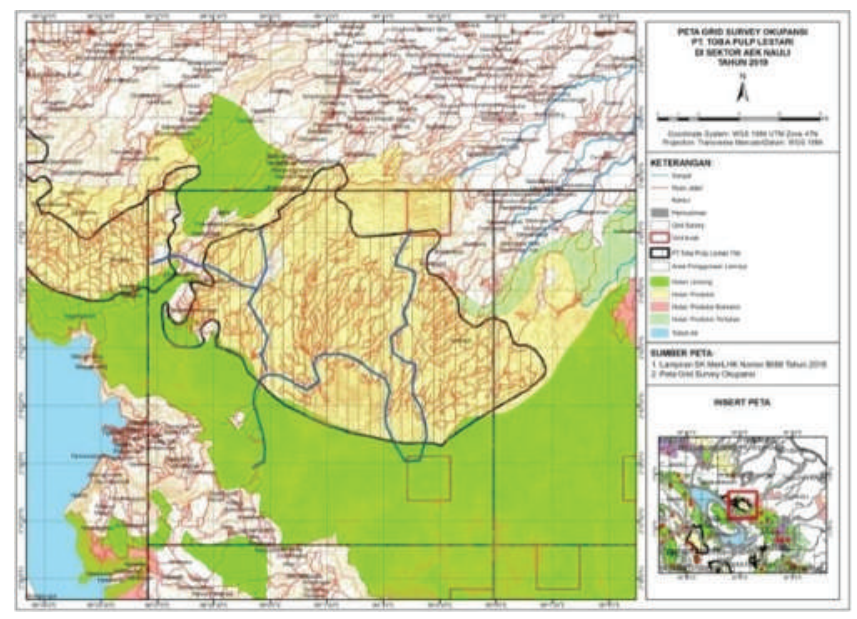

Figure 2. Sumatran Tiger Occupancy Grid in Aek Nauli Sector

Cameras were installed in the buffer zone area, KPPN (germ plasm preservation area) of Talun Sungkit, the border of Hapasuk River as well as along the Green Belt. The selection of camera installation location was not only based on the findings of tiger signs at that location, but also based on the other consideration such as altitude class, slope class and the distance from the river. The altitude class in Aek Nauli Sector area can be seen in Figure (3).

All the data recorded and obtained including the GPS coordinates of camera traps location, altitude, slope and distance from the river data which were processed using ArcGis 10.5 to produce a map of individual Sumatran tiger distribution in the Aek Nauli Sector of PT. TPL. 


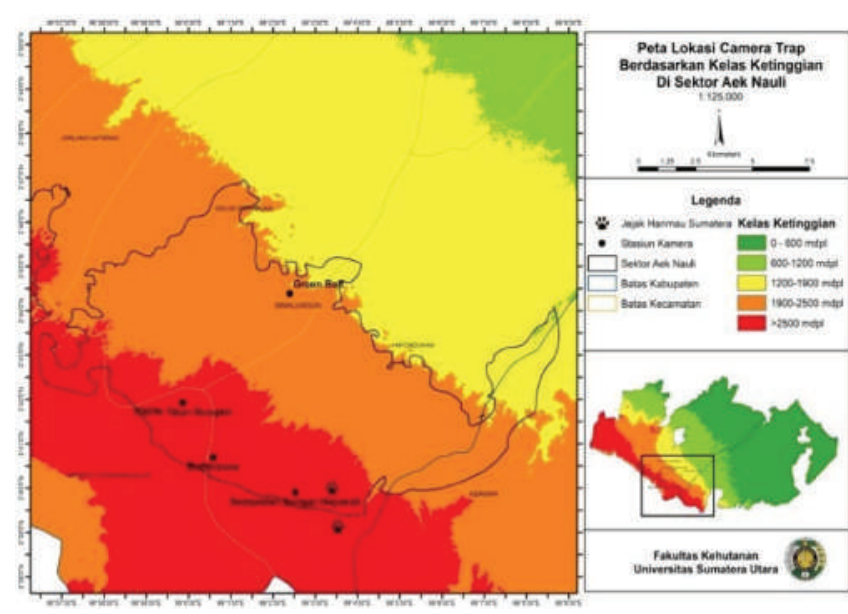

Figure 3. Location of camera traps placement based on altitude class in the Aek Nauli Sector area.

\section{RESULTS AND DISGUSSION}

The habitat of the Sumatran tiger is in lowland areas and the altitude of $0-600 \mathrm{~m}$ asl (lowland) is the best altitude to set up the camera traps. Although the Aek Nauli sector is located at $>1000 \mathrm{~m}$ asl which is a highland area, footprints of Sumatran tigers were still found based on previous occupancy surveys. Santiapilai \& Romano (1993) stated that lowland forests are the main habitat for Sumatran tigers with a density of 1-3 tigers/ $100 \mathrm{~km}^{2}$, while mountain areas is 1 tiger/100 $\mathrm{km} 2$. However, the high rate of destruction of lowland forest in Sumatra $(65-80 \%)$ has triggers the Sumatran tigers to migrate towards hill and mountain forests. The slope class is the next parameters that is considered in deciding location to install the camera traps. Data on the slope of the Aek Nauli Sector can be seen in Table 1 and Figure 4.

Table 1. Slope class of Aek Nauli Sector area.

\begin{tabular}{lcr}
\hline Sector & Slope & Area (Ha) \\
& & \\
\hline & $0-8 \%$ & $42,377.71$ \\
AEN & $8-15 \%$ & $19,713.77$ \\
& $15-25 \%$ & $9,112.75$ \\
& $25-40 \%$ & $5,229.19$ \\
& $>40 \%$ & $3,936.19$ \\
\hline \multicolumn{2}{c}{ Area sector AEN } & $80,369.62$ \\
\hline
\end{tabular}

Figure 4 shows that the camera trap location was placed at areas with slope classes of $0-8 \%$ (flat) and $8-15 \%$ (ramps). The slope class is chosen based on the habits of Sumatran tigers which are active in flat areas. According to O'Brien et. al. (2003), tigers spent all their time $(100 \%)$ in lowland areas and flat areas with a slope of $0-8 \%$. Other than the altitude and slope class, the distance to the river is another important parameter to consider for camera trap placement. A map based on the distance to the river in the Aek Nauli Sector can be seen in Figure 5.

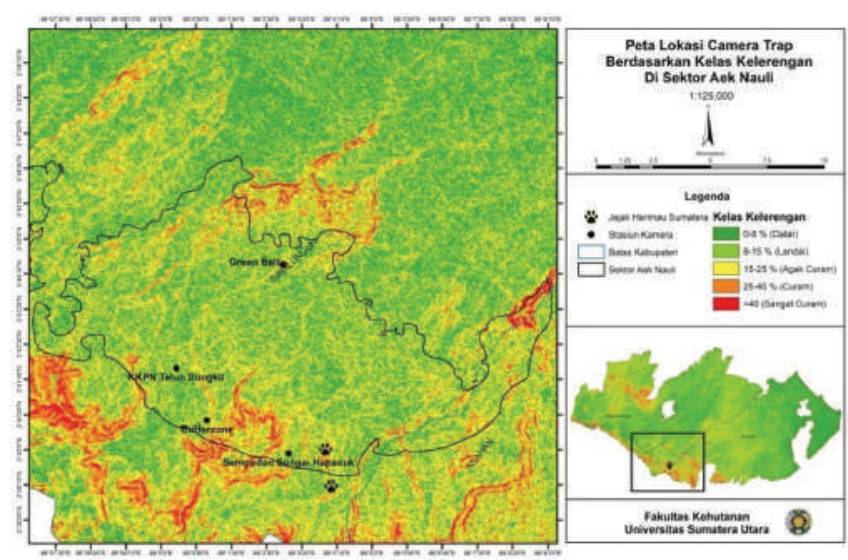

Figure 4. Location of camera traps placement based on slope class in the Aek Nauli Sector area.

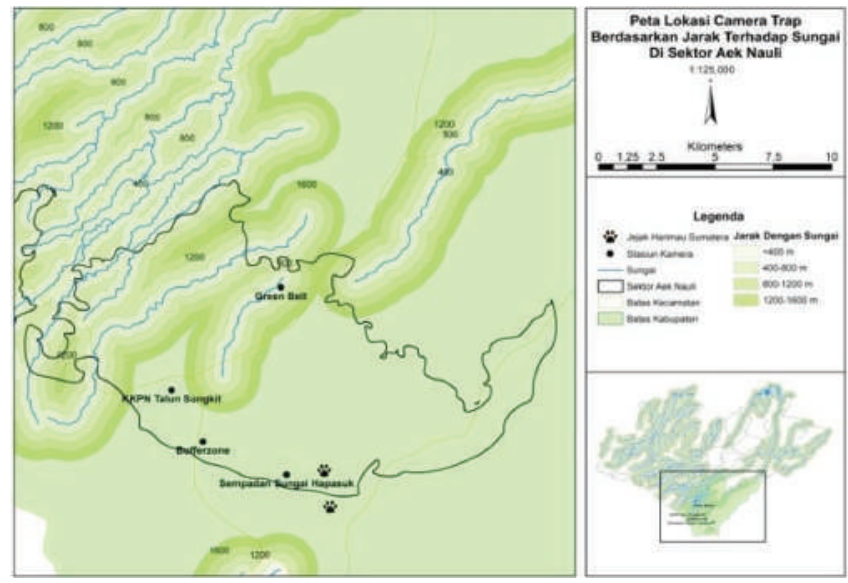

Figure 5. Location of camera traps placement based on distance to river in the Aek Nauli Sector area.

Figure 5 shows that the location of camera trap placement is close to the river. The location that is adjacent to the river is Green Belt area which has a $<400 \mathrm{~m}$ distance based on the criteria. This location is selected because it is frequently visited by the Sumatran Tigers and it is also place where the prey animals do their activity. Karanth (2001) also states that tigers are animals that love water and able to swim. River is also a gathering place for animals, and it may lead to predation when tigers are on that area. The cameras that have been installed are then removed based on the determined schedule, which is 7 days of installation in buffer zone area, the KPPN of Talun Sungkit, Hapasuk River border and 13 days in Green Belt area, which is the farthest installation station.

During the study conducted, no photograph of tiger and their main prey were found. However, our camera traps recorded other wildlife that classified as tiger potential prey such as pig-tailed macaque (Macaca nemestrina). The other wildlife species that were captured by the camera trap which are marbled cat (Pardofelis marmorata), treeshrew (Tupaia sp.), Asian palm civet (Paradoxurus hermaphroditus), lizards (Eutropis sp.), Hoogerwerf's pheasant (Lophura hoogerwerfi), and wood mouse (Apodemus sp), and birds (Figure 6). Dinata 
\& Sugarjito (2008) argue, the existence of the main prey animals is directly correlated with the existence of the tiger in an area which tiger prefer to prey wild boar, muntjac, sambar deer, mouse deer, and serow, which are their main prey, while macaque and tapir as their optional prey. Rudiansyah (2007) stated that tigers always follow the movements of their prey and are always close to their preys.

There is a direct correlation between the existence of Sumatran tiger and its prey which is also affected by the altitudinal factor. Griffith \& Schaik (1994) stated that prey species found in forest at $100-600 \mathrm{~m}$ asl altitude have higher density and diversity compared to forests at the altitude of 600-1,700 m asl. Aek Nauli is located at the altitude of $>1000 \mathrm{~m}$ asl, which means that the diversity and density of prey species is limited so that it also affects the existence of the Sumatran tigers.
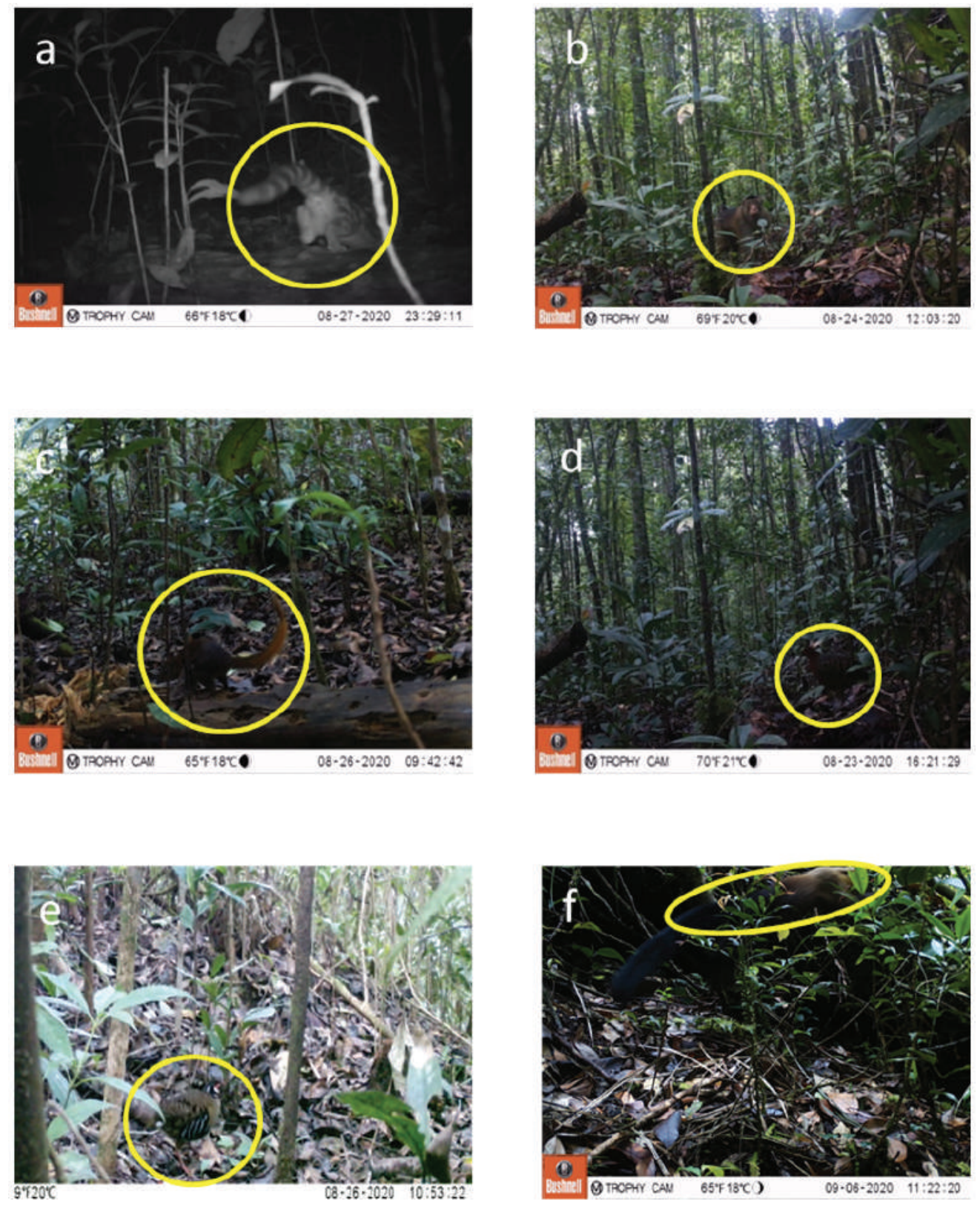

Figure 6. Wildlife species encountered by camera traps during field study in Aek Nauli Sector: (a) marbled cat (b) pig-tailed macaque (c) treeshrew (d) Hoogerwerf's pheasant (e) Hoogerwerf's pheasant (f) Asian palm civet.

\section{GONGLUSSION}

Based on the result we conclude were the presence of tiger main prey in this study area is very low and it is affected to tiger existences in this area. Camera trap operation in each location very short and cover area survey quite small could be other factors where this study could not record tiger photograph. Furthermore, regular tiger monitoring activities need to be carried out followed by conducted protection activities with 
stakeholders collaboration to conserve and maintain tiger existence in plantation forest area of PT. TPL.

\section{REFERENGES}

Dinata, Y. \& Sugardjito, J. (2008). Preferensi habitat pada harimau sumatera (Panthera tigris sumatrae) dan hewan mangsa di Taman Nasional Kerinci Seblat, Sumatera. Furnal Biodiversitas 9 (3): 222-226.

Ganesa, A. \& Aunurohim, A. (2012). Perilaku harian harimau sumatera (Panthera tigris sumatrae) dalam konservasi ex-situ Kebun Binatang Surabaya. Jurnal Sains dan Seni ITS 1 (1): E48-E53.

Griffith, M. \& Schaik, C.P. van. (1994). The impact of human traffic on the abundance and activity periods of Sumatran rain forest wildlife. Conservation Biology fournal 7 (3): 623-626.

Karanth, U. K. (2001). The Way of the Tiger: Natural History and Conservation of the Endangered Big Cat. Centre for wildlife studies, Bangalore, India.

O’Brien, T.G., Kinnaird, M.F. \& Wibisono, H.T. (2003). Crouching tiger, hidden prey: Sumatran tiger and prey populations in a tropical forest landscape. Animal Conservation 6: 131-139.
Priatna, D., Santosa, Y., Prasetyo, L.B. \& Kartono, A.P. (2012). Habitat selection and activity pattern of GPS collared Sumatra tigers. Jurnal Manajemen Hutan Tropika XVIII (3): 155-163.

Rudiansyah. (2007). Permodelan Spasial Kesesuaian Habitat Harimau Sumatera (Panthera tigris sumatrae Pocock, 1929) di Resort Ipuh-Seblat Seksi Koservasi Wilayah II Taman Nasional Kerinci Seblat. Fakultas Kehutanan Institut Pertanian Bogor, Bogor.

Santiapilai, G. \& Ramono, W.S. (1993). Conservation of Sumatran tiger (Panthera tigris sumatrae) in Indonesia. Tiger Paper 20: 44-48.

Sinaga, W.H. (2004). Pengalaman Program Konservasi Harimau Sumatera (PKHS) dalam Implementasi Konservasi Harimau Sumatera Secara Insitu di Pulau Sumatera. Prosiding Seminar Harimau Sumatera. Unit Konservasi Fauna Institut Pertanian Bogor, Bogor.

Sriyanto. (2003). Kajian mangsa harimau sumatera (Panthera tigris sumatrae Pocock 1929) di Taman Nasional Way Kambas. Tesis. Program Pascasarjana. Institut Pertanian Bogor, Bogor.

Sumitran, R., Yoza, D. \& Oktorini, Y. (2014). Keberadaan harimau sumatera (Panthera tigris sumatrae) dan satwa mangsanya di berbagai tipe habitat pada Taman Nasional Tesso Nilo. Furnal Online Mahasiswa Fakultas Pertanian Universitas Riau 1(1): 1-15. 